[Agr. Biol. Ghem., Vol. 29, No. 10, p. 936 942, 1965]

\title{
Increase in Viscosity and Gel Formation of Fruit Juice by Purified Pectinesterase
}

\author{
By Susumu Oi and Yukio Satomura \\ Faculty of Science, Osaka City University, Osaka \\ Received June 5, 1965
}

\begin{abstract}
The pectinesterase produced by Sclerotinia libertiana was purified by the column chromatography employing cation exchange resin Amberlite $\mathrm{CG} 50$ and $\mathrm{CM}$ cellulose. The specific activity per $\mathrm{mg}$ protein was increased 266-fold. The homogeneity of the enzyme preparation was confirmed by ultracentrifugal analysis and starch zone electrophoresis. The purified pectinestrase was found to remarkably increase the viscosity of pectin solution and fruit juice, and, in a pectin solution of appropriate concentration (about $0.5 \sim 1 \%$ ) and some fruit juices, it finally formed the gel, even if $\mathrm{Ca}$ salt was not added. The viscosity thus increased and gel formed by the enzyme action did not change for a long time.
\end{abstract}

\section{INTRODUCTION}

The studies on purification of pectinesterase (PE) from some microbial origins were contributive to explaining the role of $\mathrm{PE}$ in the clarification of fruit juice. ${ }^{1-5)}$

However, the effect of PE on viscosity of fruit juice has never been so far described. The pectic enzyme produced by Sclerotinia libertiana can also be used for clarification of fruit juice, and has a tolerably powerful PE activity. $^{6}$ The authors attempted the purification of PE of the fungus, and, as a result of investigating the mode of action of the purified PE, it was found that the viscosity of fruit juice is remarkably increased by $\mathrm{PE}$ and, in some juices, gelling of the solution occurs without addition of Ca salt. This fact could be used to estimate the contamination of polygalacturonase (PG) in PE. In the present paper, some physical and enzymatic properties of the purified enzyme are also

1) A. Endo, This Journal, 28, 757 (1964).

2) M. Yamasaki, A. Kato, K. Shu, T. Yasui and K. Arima, Ann. Meeting of Agr. Chem. Soc. of Japan, 1964.

3) A. Endo, This Journal, 29, 129 (1965).

4) M. Yamasaki, T. Yasui and K. Arima, This Journal, 28, 779 (1964).

5) M.Yamasaki and K. Arima, Ann. Meeting of Agr. Chem. Soc. of Japan, 1965.

6) Y. Satomura, J. Agr. Chem. Soc. of Japan, 26, 486 (1952). described.

\section{EXPERIMENTAL AND RESULTS}

Citrus Pectin. A commercial product of pectin (California Fruit Grocer Exchange product) was purified repeating the precipitation with ethanol $(80 \% \mathrm{v} / \mathrm{v})$, before use. It contained about $1.0 \%$ of ash, $0.67 \%$ of nitrogen and $5 \%$ of pentosan, and its esterification degree was $69 \%$.

Fruit Juice. Juices were freshly prepared from apples ("Kokko", and "Indo"), strawberry ("Hoko") and orange ("Hassaku") by crushing with a grater and pressing through gauzes, and, after the heat-treatment at $90^{\circ} \mathrm{C}$ for 20 min. and centrifugation at 3000 r.p.m. for 10 min., the supernatants were used.

PE Activity. The reaction mixture consisting of $5 \mathrm{ml}$ of $2 \%$ pectin solution, $1 \mathrm{ml}$ of enzyme solution, $1 \mathrm{ml}$ of $1.5 \mathrm{M} \mathrm{NaCl}$ solution and $3 \mathrm{ml}$ of water (adjusted to $\mathrm{pH} 5.0$ with $1 / 10 \mathrm{~N} \mathrm{NaOH}$, the total volume $10 \mathrm{ml}$ ) was incubated at $30^{\circ} \mathrm{C}$ for $60 \mathrm{~min}$. and carboxyl residue liberated during the incubation was titrated by $\mathrm{N} / 50 \mathrm{NaOH}$ using a glass electrode. One unit of $\mathrm{PE}$ activity was defined as that which produces $2 \times 10^{-5}$ moles of free carboxyl group under the condition. 
Viscosity. The viscosity was measured at intervals with the Ostwald viscosimeter and expressed as relative viscosity. Before the measurement, $\mathrm{pH}$ of pectin solution was adjusted to 5.5 with $\mathrm{N} / 10 \mathrm{NaOH}$. With fruit juice, $\mathrm{pH}$ was unadjusted.

TABle I. Purification Procedure of PeCtinesterase

\begin{tabular}{|c|c|c|c|}
\hline Procedure & $\begin{array}{l}\text { Volume } \\
(\mathrm{ml})\end{array}$ & $\begin{array}{c}\text { Specific } \\
\text { Activity } \\
\text { (unit/mg) }\end{array}$ & $\begin{array}{l}\text { Total } \\
\text { Activity } \\
\text { (units) }\end{array}$ \\
\hline $\begin{array}{c}\text { Extracts of bran culture } \\
\downarrow\end{array}$ & 2000 & 0.178 & 2500 \\
\hline $\begin{array}{l}\text { Ppt. with } 0.55 \text { satur. of } \\
\left(\mathrm{NH}_{4}\right)_{2} \mathrm{SO}_{4} \text { and dialyzed } \\
\text { against water for one day } \\
\downarrow \\
\text { Adjusted to } \mathrm{pH} 3.2 \text { with } \\
1.0 \mathrm{M} \text { acetate buffer and } \\
\text { centrifuged }\end{array}$ & 400 & 0.5 & 2300 \\
\hline $\begin{array}{l}\text { Supernatant } \\
\downarrow \\
\text { Duolite A2 buffered with } \\
0.1 \mathrm{M} \text { Acetate at } \mathrm{pH} 3.2 \\
\downarrow\end{array}$ & 450 & 0.6 & 1800 \\
\hline Effuent & 800 & 1.00 & 1600 \\
\hline $\begin{array}{l}\text { Ppt. with } 0.75 \text { satur. of } \\
\left(\mathrm{NH}_{4}\right)_{2} \mathrm{SO}_{4} \text { and dialyzed } \\
\text { against water for one day } \\
\downarrow \\
\text { Adsorbed on Amberlite CG } \\
50 \text { buffered with } 0.1 \mathrm{M} \\
\text { Acetate at pH } 3.2 \\
\qquad \downarrow \\
\text { Eluted with } 0.1 \mathrm{M} \text { acetate } \\
\text { buffer (pH } 4.0 \text { ) } \\
\qquad\end{array}$ & $G$ & 1.21 & 1420 \\
\hline $\begin{array}{l}\text { Eluate } \\
\text { Ppt, with } 0.9 \text { satur. of }\end{array}$ & 200 & 6.00 & 1240 \\
\hline $\begin{array}{c}\text { Ppt. with } 0.9 \text { satur. of } \\
\left(\mathrm{NH}_{4}\right)_{2} \mathrm{SO}_{4} \text { and dialyzed } \\
\text { against water for one day } \\
\quad \downarrow \\
\text { Adsorbed on } \mathrm{CM} \text { cellulose } \\
\text { column buffered with } 0.05 \mathrm{M} \\
\text { Acetate buffer at pH } 3.6 \\
\quad \downarrow \\
\text { Eluted stepwise with } 0.1 \mathrm{M} \\
\text { Acetate buffer (pH } 3.6 \sim 5.8 \text { ) } \\
\quad \downarrow\end{array}$ & $\mathrm{M}$ & 6.50 & 1160 \\
\hline $\begin{array}{l}\text { Eluate at } \mathrm{pH} 3.9 \\
\quad \downarrow \\
\text { Rechromatography on } \mathrm{CM} \\
\text { cellulose column } \\
\downarrow \downarrow \\
\text { (Purified Pectinesterase } \\
\text { fraction) }\end{array}$ & 44.4 & 47.3 & 730 \\
\hline
\end{tabular}

Purification of PE. Purification procedure is summarized in Table I. The bran culture of Sclerotinia fungus was extracted with 5 times its weight of distilled water. The extract was brought to 0.55 saturation with ammonium sulfate and allowed to stand overnight at $4^{\circ} \mathrm{C}$. The resulting precipitate was collected by centrifugation at 4,000 r.p.m. for 20 min., dissolved in a small volume of distilled water, and dialyzed against distilled water. To the dialyzed solution, acetate buffer $(\mathrm{pH}$ 3.2) was added to $\mathrm{m} / 10$ concentration. The precipitate formed was removed by centrifugation and the supernatant was passed down through Duolite A2 resin column $(5.5 \mathrm{~cm} \times$ $54 \mathrm{~cm}$ ) which had been bufferized at $\mathrm{pH} 3.2$ with $\mathrm{m} / 10$ acetate buffer, whereby the decolorized enzyme solution was obtained. To the enzyme solution ammonium sulfate was added to 0.75 saturation. The resulting precipitate was collected by centrifugation, and, after dissolving in a small volume of distlled water, dialyzed against distilled water. The dialyzed solution was adjusted at $\mathrm{pH} 3.2$ with acetate buffer ( $\mathrm{M} / 10$ in final), and passed through Amberlite CG 50 resin column $4.5 \mathrm{~cm}$ $\times 45 \mathrm{~cm}$ ) which had been bufferized $\mathrm{pH}$ at 3.2 with $\mathrm{m} / 10$ acetate buffer, whereby the PE was adsorbed on the resin. Then, the PE was eluted with $\mathrm{m} / 10$ acetate buffer ( $\mathrm{pH} 4.0$ ) and again precipitated with 0.9 saturation of ammonium sulfate. The precipitate was dissolved in a small volume of distilled water and dialyzed. The dialyzed solution was adjusted at $\mathrm{pH} 3.6$ with acetate buffer ( $\mathrm{M} / 20$ in final), and subjected to a chromatography on CM cellulose column which had been equilibrated with м/20 acetate buffer at $\mathrm{pH}$ 3.6. The column was eluted with $\mathrm{m} / 10$ acetate buffer whose $\mathrm{pH}$ was changed stepwise from 3.6 to 5.8. As presented in Fig. 1, the $\mathrm{PE}$ was eluted at nearly $\mathrm{pH} 4$. The $\mathrm{PE}$ fraction obtained was subjected to rechromatography on $\mathrm{CM}$ cellulose, as shown in Fig. 2. In this step, the activity of PE was attained to 266-fold per mg protein. 


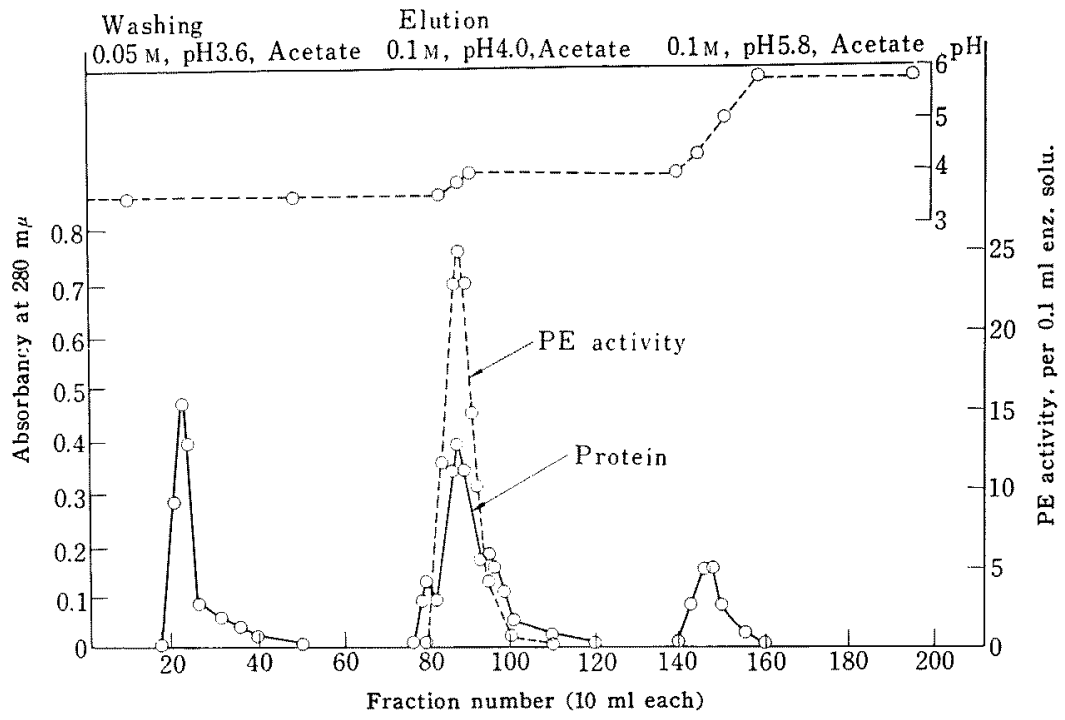

FIG. 1. Chromatography of PE on CM Cellulose Column, $(2.1 \times 54 \mathrm{~cm})$.

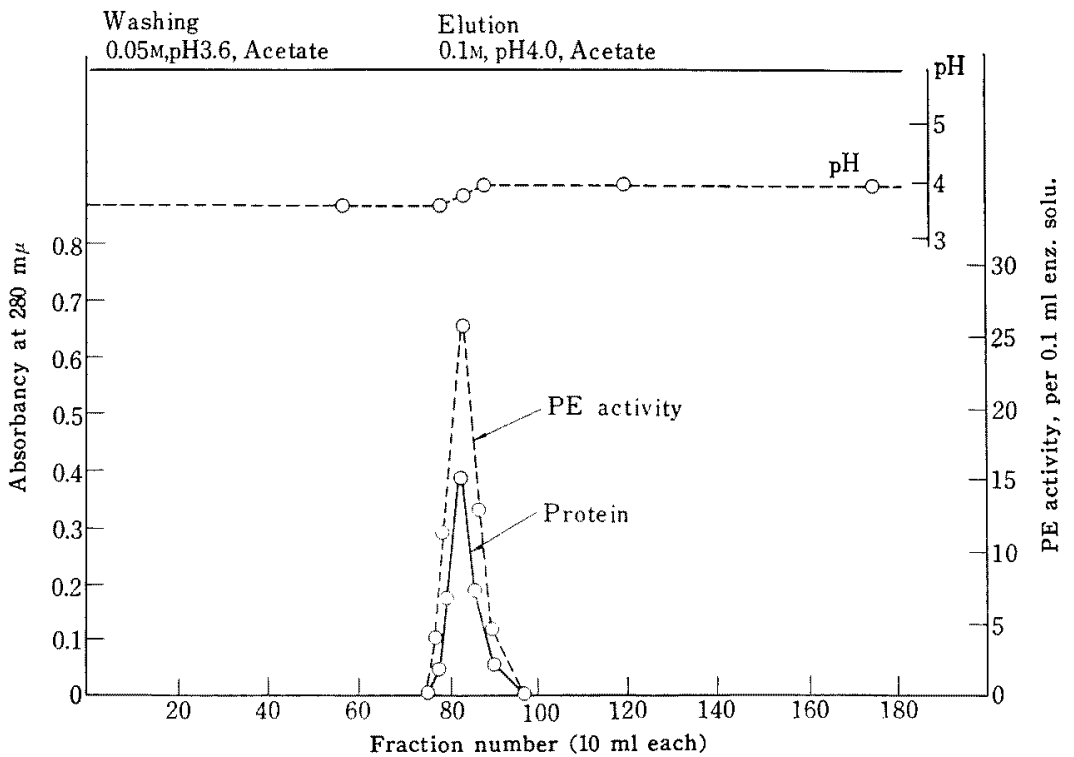

FIG. 2. Rechromatography of PE on CM Cellulose Column, $(2.1 \times 60 \mathrm{~cm})$.

Some Properties of the purified PE

i) Electrophoresis. Starch zone electrophoresis was performed according to the method of
Kunkel," using a starch block encased in

7) H.G. Kunkel, "Methods of Biochemical Analysis.", Interscience Publishers Press, (I954), 1, p. 156. 
plastic case $(30 \times 3 \times 1 \mathrm{~cm})$ and $\mathrm{m} / 50$ tris buffer $(\mathrm{pH}$ 8.2). About $4.3 \mathrm{mg}$ of the purified $\mathrm{PE}$ was, after dissolving in $2 \mathrm{ml}$ of the tris buffer and dialyzing against the same buffer overnight, placed on the starch block in $1.0 \mathrm{~cm}$ wide and at the distance of $10 \mathrm{~cm}$ from the cathode side. After electrophpretic movement was conducted at 250 volt, $8 \mathrm{~m}$ amp. and $4^{\circ} \mathrm{C}$ for $8 \mathrm{hrs}$, the starch block was segmented to $1 \mathrm{~cm}$ intervals with a spatula. To each segment, $5 \mathrm{ml}$ of water was added, followed by stirring at $4^{\circ} \mathrm{C}$ for $20 \mathrm{hrs}$. and then the extracts obtained by filtration were analyzed for the enzyme activity and optical density. The result is shown in Fig. 3. The PE exhibited a single main peak, the center of which was present at $2 \mathrm{~cm}$ from the original point, though a small amount of impurities was recognized at $8 \sim 10 \mathrm{~cm}$. from the point.

ii) Ultracentrifugal Analysis. Prior to analysis, the $\mathrm{PE}$ was dissolved in $\mathrm{M} / 10$ phosphate buffer $(\mathrm{pH} 7.0)$ and dialyzed against the same buffer overnight. The dialyzed enzyme solution containg about $6.33 \mathrm{mg}$ of protein per $\mathrm{ml}$ was subjected to the sedimentation with a Hitach UCA-1 ultracentrifuge at 60,000 r.p.m. and $20.5^{\circ} \mathrm{C}$. As shown in Fig. 4, in each

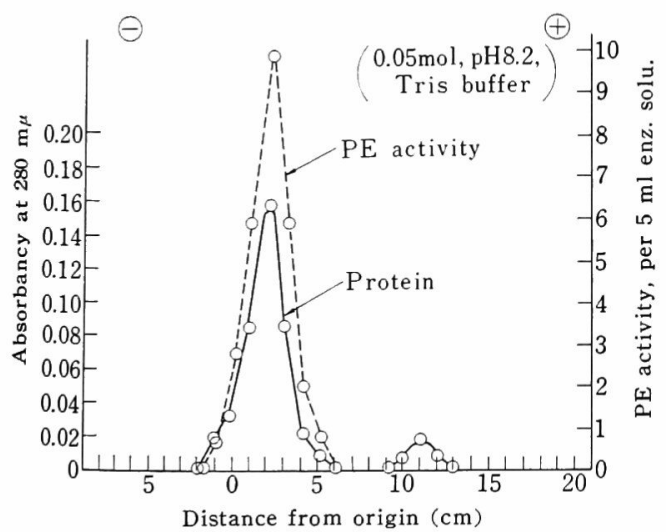

FIG. 3. Starch Zone Electrophoretic Pattern of PE.

$$
\begin{array}{ll}
\text { Starch block; } & 1 \times 3 \times 30 \mathrm{~cm}, \\
\text { condition } ; & 250 \mathrm{~V}, 8 \mathrm{mamp} . \\
\text { Temperature; } & 4^{\circ} \mathrm{C}, \\
\text { Time } ; & 8 \mathrm{hrs} .
\end{array}
$$

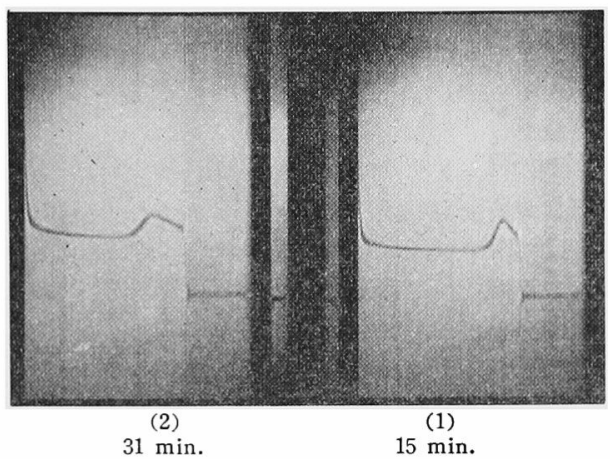

Fig. 4. Sedimentation Pattern of PE by Ultracentrifugation.

$\begin{array}{ll}\text { Protein concentration; } & \text { about } 6.33 \mathrm{mg} / \mathrm{ml} \\ \text { Revolution } & ; 60,000 \text { r.p.m. } \\ \text { Temperature } & ; 20.5^{\circ} \mathrm{C} \\ \text { Bar angle } & ; 55^{\circ}\end{array}$

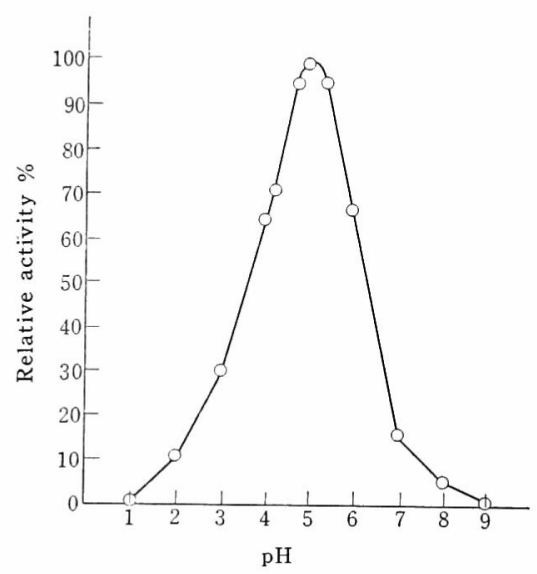

FIG. 5. pH-Activity.

case at 15 and $31 \mathrm{~min}$. after reaching the maximal speed of revolution, presence of a single component was proved. The sedimentation coefficient was calculated to be $4.41 \mathrm{~S}$. iii) Opt. pH, pH Stability and Thermostability. As shown in Fig. 5 and 6, the optimum $\mathrm{pH}$ was about $4.8 \sim 5.2$ in acetate buffer, and in a range of $\mathrm{pH} 4.0 \sim 5.0$ the enzyme was most stable. Also, as shown in Fig. 7, after the incubation at $\mathrm{pH} 4.0$ and $55^{\circ} \mathrm{C}$ for $5 \mathrm{~min}$. a half of the enzyme activity still remained.

iv) Hydrolysis Rate of Pectin. The hydrolysis 


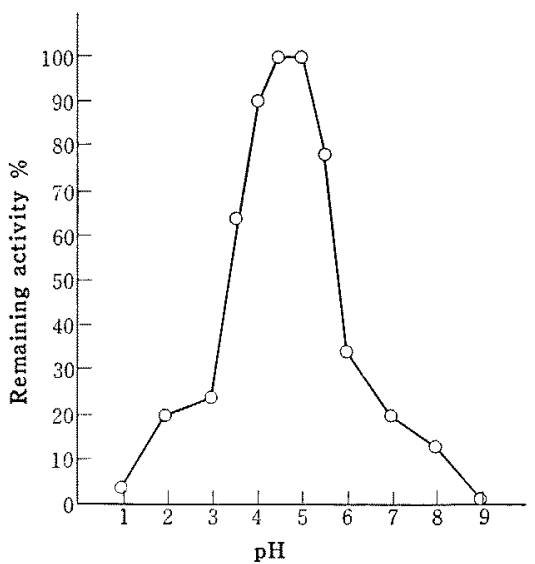

FIG. 6. pH-Stability. (Incubated at $30^{\circ} \mathrm{C}$, for $22 \mathrm{hrs}$.)

TABLE II. EFFECTS OF METALS AND SOME SURFACE ACTIVE AGENTS

\begin{tabular}{|c|c|c|}
\hline Addition & Concn. & $\begin{array}{c}\text { Relative Activity } \\
\text { (at } \mathrm{pH} 5.0 \text { ) }\end{array}$ \\
\hline Control & - & 100 \\
\hline \multirow[t]{3}{*}{$\mathrm{NaCl}$} & $0.15(\mathrm{M})$ & 127 \\
\hline & 0.02 & 110 \\
\hline & 0.01 & 100 \\
\hline \multirow[t]{2}{*}{$\mathrm{KCl}$} & 0.05 & 100 \\
\hline & 0.01 & 95 \\
\hline \multirow[t]{2}{*}{$\mathrm{CaCl}_{2}$} & 0.02 & 74 \\
\hline & 0.005 & 110 \\
\hline \multirow[t]{2}{*}{$\mathrm{MnCl}_{2}$} & 0.02 & 74 \\
\hline & 0.005 & 87 \\
\hline \multirow[t]{2}{*}{$\mathrm{MgCl}_{2}$} & 0.02 & 67 \\
\hline & 0.005 & 100 \\
\hline \multirow[t]{2}{*}{$\mathrm{CoCl}_{2}$} & 0.02 & 20 \\
\hline & 0.005 & 70 \\
\hline \multirow[t]{2}{*}{$\mathrm{NiCl}_{2}$} & 0.02 & 45 \\
\hline & 0.005 & 95 \\
\hline \multirow[t]{2}{*}{$\mathrm{ZnCl}_{2}$} & 0.02 & 20 \\
\hline & 0.005 & 80 \\
\hline \multirow[t]{2}{*}{$\mathrm{MgCl}_{2}$} & 0.02 & 67 \\
\hline & 0.005 & 80 \\
\hline \multirow[t]{2}{*}{ Na-Desoxycholate } & 0.005 & 85 \\
\hline & 0.002 & 123 \\
\hline \multirow[t]{2}{*}{$\mathrm{Na}-$ Taurocholate } & 0.005 & 90 \\
\hline & 0.002 & 90 \\
\hline \multirow[t]{2}{*}{ Saponin (Soy bean) } & $0.01 \%$ & 81 \\
\hline & $0.001 \%$ & 100 \\
\hline EDTA & $\mathrm{M} / 800$ & 50 \\
\hline
\end{tabular}

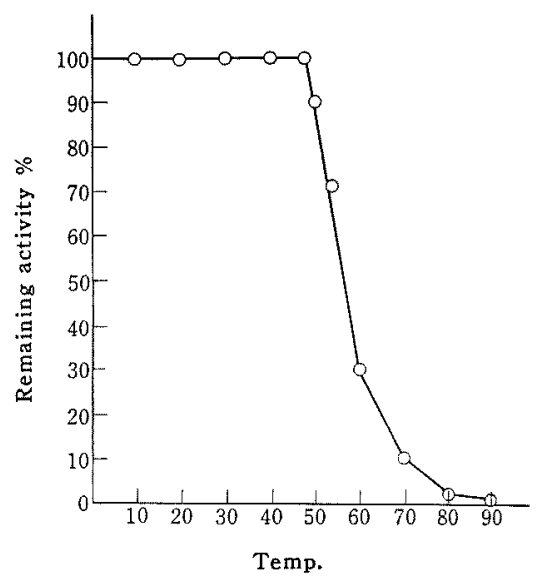

FIG. 7. Heat-Stability.

(Incubated at $\mathrm{pH} 4.0$ for $5 \mathrm{~min}$, in $0.1 \mathrm{~mol}$. Acetate)

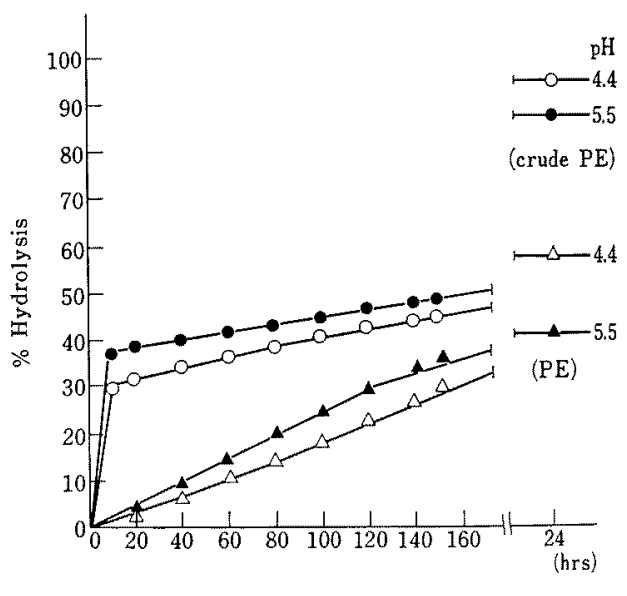

Min. (hrs.)

FIG. 8. Hydrolysis Curves of Pectin by PE.

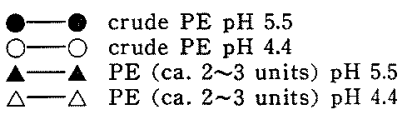

of pectin by the purified $\mathrm{PE}$ at $\mathrm{pH} 4.4$ and 5.5 is shown in Fig. 8. At pH 5.5, the hydrolysis by PE with 2 units of the activity reached to $30 \%$ in $2 \mathrm{hrs}$. and finally $38 \%$ in 24 hrs. At $\mathrm{pH} \mathrm{4.4,} \mathrm{the} \mathrm{hydrolysis} \mathrm{rate} \mathrm{was} \mathrm{at}$ first a little lower than that with $\mathrm{pH} 5.5$, but, afterwards, became higher and finally extended to $58.3 \%$ in $24 \mathrm{hrs}$. 
v) Effect of Metals. As shown in Table II, the activity of $\mathrm{PE}$ was increased by $\mathrm{NaCl}$ $(0.02 \sim 0.15 \mathrm{M})$ and inhibited by $\mathrm{Co}^{++}, \mathrm{Ni}^{++}$, $\mathrm{Mn}^{++}, \mathrm{Mg}^{++}$, and $\mathrm{Zn}^{++}$salts $(0.02 \sim 0.005 \mathrm{M})$. $\mathrm{Ca}^{++}$salt was also inhibitive, but rather stimulative in a dilute concentration $(0.005 \mathrm{M})$.

Some surface active agents such as Na-desoxycholate, Na-taurocholate and saponin were all inhibitive, but $\mathrm{Na}$-desoxycholate in the concentration of $0.002 \mathrm{M}$ was stimulative. Ethylenediaminetetra-acetate (EDTA, м/800) inhibited about $50 \%$ of $\mathrm{PE}$ activity.

Viscosity Gel Change and Gel Formation of Pectin Solution and Fruit Juice by PE

i) Pectin Solution. The reaction mixture, as described above in the measurement of $\mathrm{PE}$ activity (pectin; $1 \%, \mathrm{NaCl} ; 0.15 \mathrm{M}$, in final, and $\mathrm{PE} ; 4 \mathrm{U}$.), was incubated at $30^{\circ} \mathrm{C}$, and kept at $\mathrm{pH} 5.5$ with $\mathrm{N} / 10 \mathrm{NaOH}$. As presented in Fig. 9. viscosity of the pectin solution increased gradually at first, then rapidly, and, finally, the viscous solution gelled in about 3 hrs. With $0.5 \%$ pectin solution the gel formation also occurred in $18 \mathrm{hrs}$. (Fig. 10). The rate of hydrolyzed ester bonds at that time was about $20 \%$ and did not so proceed, afterwards. At pH 3.6 and in $\mathrm{NaCl}$-free

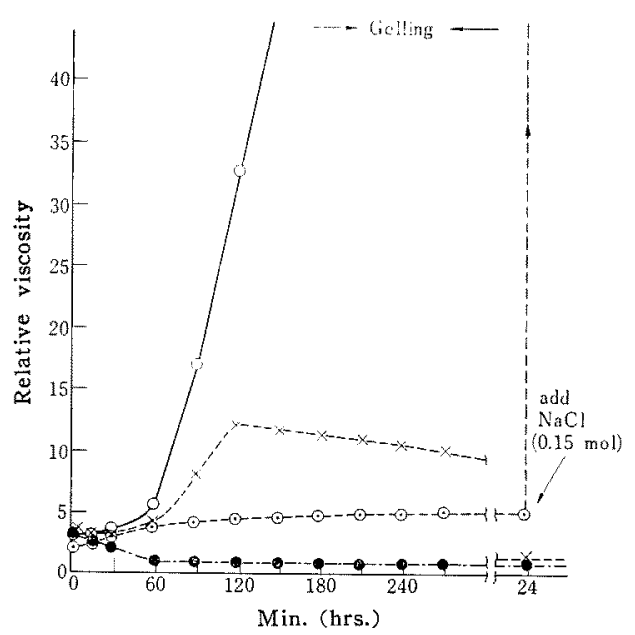

Fig. 9. Viscosity Change and Gel Formation of Pectin Solution by PE.

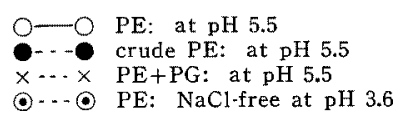

medium the viscosity-increase was slight and the gel formation did not occur even after 24 hrs., but here the addition of $\mathrm{NaCl}(0.15 \mathrm{M}$ in final) immediately raised the viscosity and formed the gel. If a small activity of polygalacturonase $(\mathrm{PG})$ was added to $\mathrm{PE}$, the vis-

TABLE III. Viscosity INCREASE AND Gel Formation of VARIous Fruit Juices by PE

\begin{tabular}{|c|c|c|c|c|c|c|c|c|c|}
\hline \multirow[b]{2}{*}{ Juices } & \multirow[b]{2}{*}{ Pectin added } & \multicolumn{7}{|c|}{$\begin{array}{l}\text { Relative Viscosity } \\
\text { Time (min.) }\end{array}$} & \multirow[b]{2}{*}{$18(\mathrm{hrs})$} \\
\hline & & $\mathrm{PE}$ (unit) & $\mathrm{pH}$ & 0 & 60 & 75 & 135 & 200 & \\
\hline \multirow[t]{5}{*}{ Apple ("Kokko") } & 0 & 0 & 3.6 & 1.8 & 1.8 & 1.8 & 1.8 & 1.8 & 1.8 \\
\hline & $0.1 \%$ & $2 u$ & 3.6 & 2.2 & 2.35 & - & 2.95 & 3.8 & 4.0 \\
\hline & $0.2 \%$ & $2 u$ & 3.6 & 2.4 & 2.6 & - & 3.70 & 6.0 & 7.5 \\
\hline & $0.5 \%$ & $2 u$ & 3.6 & 3.0 & 3.5 & - & 7.0 & 11.0 & $\infty$ gelled \\
\hline & 0 & $2 u$ & 3.6 & 2.0 & 2.05 & - & 2.4 & 2.7 & 2.75 \\
\hline \multirow[t]{3}{*}{ Apple ("Indo") } & 0 & $2 u$ & 4.4 & 4.3 & - & 3.7 & 5.4 & $\infty$ gelled & \\
\hline & $0.2 \%$ & $2 u$ & 4.4 & 5.4 & - & 5.4 & 8.7 & $\infty$ gelled & \\
\hline & $0.5 \%$ & $2 u$ & 4.2 & 7.1 & - & 7.1 & 7.7 & $\infty$ gelled & \\
\hline \multirow[t]{3}{*}{ Strawberry } & 0 & 0 & 4.0 & 11.7 & - & 11.7 & 11.5 & 10.9 & 10.0 \\
\hline & 0 & $2 u$ & 4.0 & 11.7 & - & 10.0 & 8.5 & 12.3 & $\infty$ gelled \\
\hline & $0.2 \%$ & $2 u$ & 4.0 & 12.3 & 一 & 12.0 & 13.3 & 16.8 & $\infty$ gelled \\
\hline \multirow[t]{3}{*}{ Orange } & 0 & $2 u$ & 3.8 & 1.4 & 1.4 & 1.4 & 1.4 & 1.4 & 1.4 \\
\hline & $0.2 \%$ & $2 u$ & 3.8 & 1.9 & 1.89 & 1.88 & 2.15 & 3.7 & $\infty$ gelled \\
\hline & $0.5 \%$ & $2 u$ & 3.8 & 3.0 & 2.95 & 2.90 & 3.0 & 3.2 & $\infty$ gelled \\
\hline
\end{tabular}


cosity of the pectin solution at first increased but soon decreased gradually. The crude PE, which contained substantial activity of PG, immediately decreased the viscosity.

ii) Fruit Juice. To $10 \mathrm{ml}$. of fruit juice, 0.1 ml. of PE (about 2 units) solution was added and incubated at $30^{\circ} \mathrm{C}$. During the incubation, $\mathrm{pH}$ was unadjusted, and the results are shown in Table III. With apples, the viscosity of juices gradually increased in 2 or $3 \mathrm{hrs}$, and, with the variety "Indo", the juice soon gelled without addition of pectin. While, the juice from the variety "Kokko" did not gell without external pectin. The addition of pectin to these juices $(0.2 \sim 0.5 \%$ in final) promoted the viscosity-increase and gel-formation. A photograph of the gel is shown in Fig. 10. With strawberry, though the viscosity rather fell for a time (about $2 \mathrm{hrs}$ ), but soon rose, and the gel formation occurred in $18 \mathrm{hrs}$. With orange juice, the viscosity unchanged but, by adding pectin, increased, finally forming the gel in $18 \mathrm{hrs}$. The gels thus formed from various juice by $\mathrm{PE}$ did

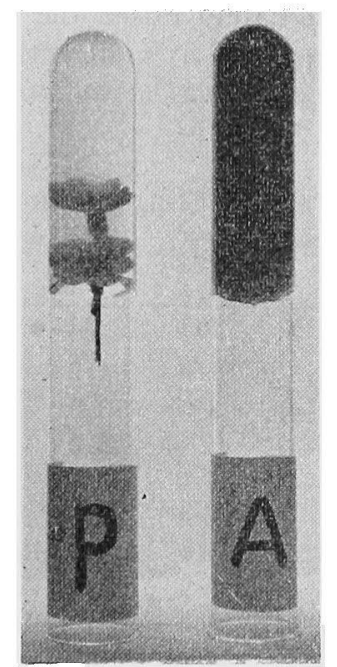

FIG. 10. Gel-Formation of Apple Juice, and Pection Solution by PE.

P: $0.5 \%$ Pectin Solution

A: Apple Juice ("Indo") $+0.2 \%$ Pectin in final not degrade after the storage for 6 months at room temperature.

\section{DISCUSSION}

Lately, two PE fractions were isolated from the culture extract of Coniothyrium diplodiella by A. Endo, and no significant difference was observed in the characteristics of the two fractions. ${ }^{11}$ In the present work, though one PE fraction has been purified from the Sclerotinia fungus, there was actually another PE fraction corresponding to $10 \sim 20 \%$ in the total activity, which was not adsorbed on cation exchange resin Amberlite CG 50 at $\mathrm{pH}$ 3.2. The characteristic of the latter seems to differ from the purified PE.

Formerly, it had been known that the presence of a certain bimetallic ion such as $\mathrm{Ca}^{++}$, $\mathrm{Ba}^{++}$or $\mathrm{Sr}^{++}$is necessary for the gel formation of pectin solution by $\mathrm{PE}$, because such bimetallic pectate forms the gel. However, the above purified PE did not need these metal ions for the gel formation of pectin solution. In this case, the gel must be formed from a low methoxyl pectin (pectinic acid) and not from pectic acid, because the hydrolysis rate of pectin by the $\mathrm{PE}$ is very low. The viscosity of pectinic acid (esterification degree 35 50\%) increases with the dropping of $\mathrm{NaOH}$, and shows the maximum at around $\mathrm{pH} 6$. Then it seems reasonable that the optimum $\mathrm{pH}$ of $\mathrm{PE}$ for increasing the viscosity and gelling of pectin solution was about 5.5 (opt. $\mathrm{pH}$ of $\mathrm{PE}$ for hydrolysis of pectin, 4.8 5.2). Also, it seems of significance that the addition of $\mathrm{NaCl}$ $(0.15 \mathrm{~m}$ in final) caused the gelling of pectin solution by $\mathrm{PE}$ even at $\mathrm{pH}$ 3.6. With fruit juice, a certain protein or amino acid may be involved in the gel formation, and also, the $\mathrm{pH}$ of fruit juice may have a close relation to this.

When PE decreases the viscosity of pectin solution, it seems necessary to examine the contamination of PG. 